\section{The FOMC in 1993 and 1994: Monetary Policy in Transition}

\section{Michael R. Pakko}

$n$ the surface, an analysis of monetary policy in 1993 and 1994 would seem to be a study in contrasts. During 1993, there were no changes in the policy directives of the Federal Open Market Committee (FOMC), and short-term interest rates remained steady throughout the year. In 1994, on the other hand, the FOMC announced six separate policy changes, each associated with highly publicized increases in short-term interest rates. From a broader perspective, monetary policy over the past two years could be characterized as reflecting an evolution of the Federal Reserve's instrument settings in response to strengthening economic growth. Policy remained deliberately stimulative during 1993, as members of the FOMC cautiously evaluated the robustness of the ongoing economic recovery. A careful reading of the policy record of the FOMC and statements by its members, however, reveals that a shift to a more-neutral policy stance was viewed as quite likely, though the timing of the policy adjustments was in question.

Beyond the short-term adjustments in the Federal Reserve's policy setings during 1994 , a number of additional themes characterize monetary policy in 1993 and 1994. Over the course of these two years, the relationships of the monetary aggregates to economic activity continued to depart from historical patterns. As a result, the strategy of using monetary aggtegates as intemediate targets has become less important in the process of formulating policy and communicating its intent to the public. At the same time, however, a broad- ening of consensus regarding the ultimate goals and limitations of monetary policy has continued to develop: Economists and Federal Reserve policynakers increasingly agree that price stability should be the overriding long-run concern of the central bank, serving as a fotndation for mantaining economic growth.

Monetary policy in 1993 and 1994 might therefore be characterized as a period of transition. Only in hindsight will we know the ultimate outcome of this process. This article seeks to describe the nature of the evolution to date. The next section describes the nature of the multi-stage policy process embodied in the framework of intermediate targeting. Subsequent sections are organized within the structure of this framework, focusing on the way in which the intermediate targeting strategy has evolved during the past two years. In particular, the article examines the growing consensus for price stability as the ultimate objective of monetary policy describes the continuing de-emphasis of monetary aggregate targeting, and discusses some issues relating to the characterization of short-run policy in 1993 and 1994 ,

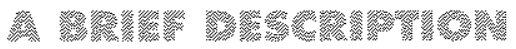

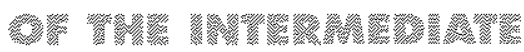

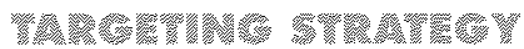

Since at least the 1970s, the Federal Reserve's monetary policy has followed a multi-stage process, often referred to as the "Intermediate Targeting" approach." The underlying presumption of this strategy is that some set of observable economic variables can serve as indicators or operational targets of monetary policy in a way that provides information about the links between specific policy actions and the ultimate goals of policy.

Typically, the intermediate targeting strategy is presented in the economic literature as a sequence of four levels of policy. At the most basic level are the tools of monetary policy - the fundamental instruments over which the Federal Reserve exerts direct control.
As a committee, the FOMC rapre sents a range of individan viewpoints. This atide toes not seok to cheracterize the views of any particutar member, nor does it represent oficidiol positions of the Committe. Rather, it rifterts one interpatettion of recent everts and decisions of the EOMC.

Tee Metilendyke (1990) for on accosint of the histoic evalutiten of the Feat's operoting procedures and internedilate targeting stotegy. 
These tools include reserve requirements, the discount rate and open market operations.

The next stage, often referred to as the operating instruments or proximate targets of policy, consists of measures which are directly affected by policy actions, but which are not under the direct control of the Federal Reserve. Included in this category are those variables that provide information on the market for bank reserves. The actions of the Federal Reserve's open market operations directly affect the supply of reserves available to the banking system. Hence, readings or conditions in the reserve market can be drawn by observing either the quantity of reserves (measured by some reserve aggregate or its growth rate) or the interest rate in the market for inter-bank reserve lending (the federal funds rate).

On the next level are the intermediate targets of policy. Theoretically, intermediate targets should have two key attributes: They must be affected by the actions of monetary policy and have a predictable relationship to the ultimate goals of policy. An ideal intermediate target would therefore serve to provide timely information on the implications of policy actions, allowing policymakers to make mid-course corrections in response to readings on the intermediate target. As the monetary policy process has evolved over recent decades, the intermediate targeting strategy has developed around the notion of using monetary aggregates as intermediate targets. In fact, the use of monetary aggregates is reflected in the congressional mandate given to the Fed to guide the conduct of policy, requiring that the Fed report "objectives and plans...with respect to the ranges of growth or diminution of the monetary and credit aggregates...."

Finally, at the end of the spectrum are the ultimate goals of monetary policy. The success or failure of policy can only be meaningfully judged by its ability to achieve these goals. Yet the particular criteria for making such a judgment have not always been apparent. Congress has legistated a number of objectives for the Fed to pursue, which include economic growth, high employment, stable prices and low long-term interest rates. If the various

Public Low 95.523, The Eull Employment and Balanced Growtí Act of 1978 , Sec. 108. objectives seem, at times, to be incompatible with one another, the legislation leaves unclear how conflicts should be resolved.
Within the intermediate targeting framework, the policymaking process can be thought of as involving strategic and tactical decisions relating the settings at the various levels. As mandated by the Full Employment and Balanced Growth Act of 1978 (otherwise known as the Humphrey-Hawkins Act), the FOMC evaluates its longer-term objectives twice per year, reporting to the Congress on its projections for economic activity, and presenting its intermediate targeting objectives in terms of monetary aggregate growth ranges. This bi-annual exercise can be thought of as establishing the objectives and strategy of policy. At each of its eight meetings per year, the FOMC makes this strategy operational by providing a "directive" to the Manager of the System Open Market Account at the Federal Reserve Bank of New York. This directive specifies a short-term operating objective, cast qualitatively in terms of a "degree of pressure on [bank] reserve positions." The directive also suggests the Committee's inclination toward modification of policy during the intermeeting period. The officials at the Open Market Desk then carry out the tactical aspects of the policy, arranging day-to-day purchases or sales of Treasury securities to achieve the Committee's objectives for proximate targets (for example, the federal funds rate and reserve aggregate growth), in some cases adjusting the instrument settings in response to incoming information regarding the intermediate target variables.

Figure 1 illustrates the process in a stepby-step manner in a way which indicates the links among the various stages and suggests the type of feedback rules with which policy is evaluated and modified. The strategic decisions of the FOMC are represented by the directional arrows running from ultimate objectives back toward the tools of policy, while the tactical decisions of short-run policy implementation run in the opposite direction.

As the structure of the economy and economists' tunderstanding of its mechanisms change over time, the Federal Reserve's approach to policymaking has evolved to meet new challenges. This evolution of the structure of policymaking is perhaps more significant than the day-to-day and month-to-month adjustments of the Fed's policy instruments, 
but is often overlooked in analyses of monetary policy. Subsequent sections of this article examine some of the emerging trends in the adaptation of the FOMC's policymaking approach, organized within the context of the intermediate targeting framework.

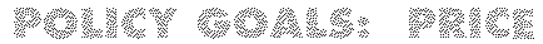

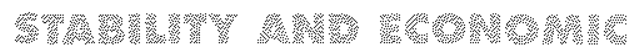

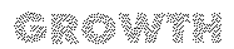

By tradition and legislation, the Federal Reserve is charged with considering a number of objectives in the formulation of monetary policy. For example, the Federal Reserve Act as amended in 1977 specifies that the Fed is to "promote effectively the goals of maximum employment, stable prices, and moderate long-term interest rates." "Federal Reserve policymakers also seek to maintain "orderly" financial markets, which operationally has meant an apparent tendency to smooth interest rate changes.

The existence of multiple goals raises the possibility that two or more objectives may come into conflict. Although congressional legislation specifies a number of goals, it gives no clear guidance how potential conflict among objectives should be resolved. Historically, Federal Reserve policymakers have tended not to specify the relationships among the goals explicitly or how potential conflicts are to be resolved, preferring instead to defer to the need to retain flexibility in the implementation of policy. As Maisel (1973) noted: "Frequently, members of the FOMC argued over the merits of a policy without ever having arrived at a meeting of the minds as to what monetary policy was and how it worked. These problems were, and still are, neither recognized nor clarified."

Recently, however, public statements by FOMC members have tended to emphasize the long-run consistency between the objectives of "price stability" and economic growth, recognizing that the trade-off which was once commonly thought to exist between inflation and real economic growth does not exist in the long run (see the shaded insert titled, "Statements by FOMC Members on Price Stability"). This view has been shaped both by theoretical advances in macroeco-

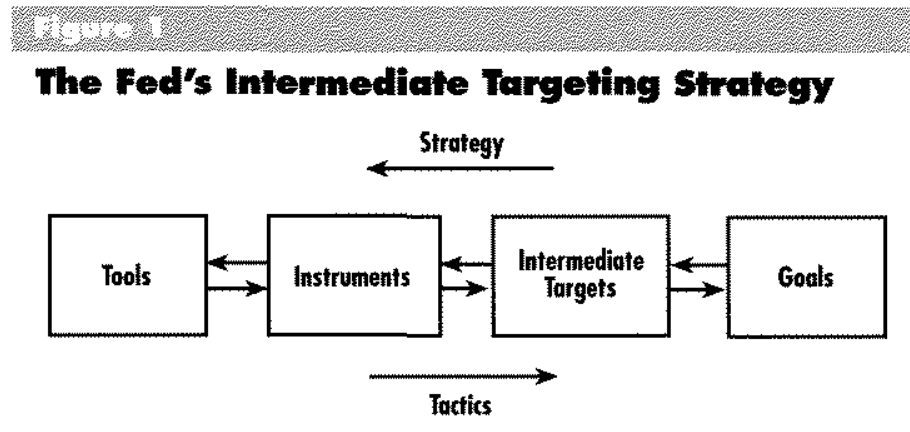

nomics and the experience of the 1970s in particular. As Federal Reserve Chairman Alan Greenspan has noted:

"...the experience of the past three decades has demonstrated that what appears as a tradeoff between unemployment and inflation is quite ephemeral and misleading. Over the longer run, no such tradeoff is evident... Experience both here and abroad suggests that lower levels of inflation are conducive to the achievement of greater productivity and efficiency and, therefore, higher standards of living."

From this perspective, the trade-offs among the various goals of monetary policy appear less in conflict with one another than they are often perceived to be: In the long run, the pursuit of price stability is consistent with-perhaps even necessary for-the maintenance of economic growth and low long-term interest rates. This view also stands in contrast to many characterizations of recent monetary policy by the media, which suggest that the Fed's policy is to deliberately impede economic growth in order to subdue inflation.' Nevertheless, there is often pressure from outside the Federal Reserve to pursue policies which promise to provide short-term gains in output and employment, but at the expense of potential inflationary consequences in the longer term."

Despite the general support for price stability, such broad statements of purpose remain somewhat vague as operational objectives. As Chairman Greenspan described the issue: "...price stability does not require that measured inflation literally be zero but rather is achieved when inflation is low enough that changes in the general price level are insignif-

\footnotetext{
${ }^{4}$ Fededul Reserve Reform Act, Section 2A, Novembe: 16,1977 (91 Stat. 1397 ).

${ }^{5}$ Maise: (1973), p. 78

Statentent before the Joint Economic Committee, US. Congess, January 31, 1994. Federal Reserve Buhatin (Morch 1994, p. 232).

For 0 critique of this viaw, see Jotdon ( 1994$)$.

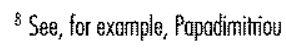
and Wroy (1994).
} 


\section{STATEMENTS BY FOMC MEMBERS ON PRICE STABILITY}

While their views often differ in emphasis and with regard to specific policy recommendations, members of the FOMC display a broad unanimity of opinion regarding the ultimate long run objectives of monetary policy:

"...the Federal Reserve seeks to foster maximum sustainable economic growth and rising standards of living. And in that endeavor, the most productive function the central bank can perform is to achieve and maintain price stability."

- Alan Greenspan, Chatrman, Federal Reserve Board

"Inflation has to, by default, take primacy because that is what we can control in the long run.".

- Alan Blinder Vice Chairman. Federal Reserve Board

"The Federal Reserve is committed to keeping inflation down not for its own sake, but because it is important for longterm economic growth for this country."

$$
\text { - Lawrence B. Lindsey, member, }
$$
Federal keserve Board

"I think in general we've made good progress on price stability, but it's not something where you can say, 'We've won the battle and we can go home.' It's something we always have to pay attention to."

$$
\begin{array}{r}
\text { - Susan M. Phillips, member, } \\
\text { Federal Reserve Board }
\end{array}
$$

"Keeping inflation low is a necessary ingtedient for maximizing sustainable economic and job growth."

$$
\begin{gathered}
\text { - Edward G. Boehne, President, } \\
\text { Federal Reserve Bank } \\
\text { of Philadelphia }
\end{gathered}
$$

"What monetary policy can do to promote long-run economic efficiency is to stabilize the aggregate price level and to create a climate of confidence about the outlook for price stability."

$$
\begin{aligned}
& \text { - Jerry L. Jordan, President, } \\
& \text { Federal Reserve Bank } \\
& \text { of Cleveland }
\end{aligned}
$$

"I believe that the primary goal of policy is to promote economic growth and employment and that the Federal reserve can best pursue this goal by fostering a stable aggregate price level over time."

$$
\text { - J. Alfred Broaddus, Jr, President, }
$$
Federal Reserve Bank of Richmond

"We now know that maximum sustainable economic growth is achieved when changes in the price level cease to be a factor in economic decision-making."

$$
\begin{aligned}
& \text { - Thomas C. Melzer, President, } \\
& \text { Federal Reserve Bank } \\
& \text { of St. Louis }
\end{aligned}
$$

"... in the long run the most significant contribution monetary policy can make to achieving maximum sustainable growth in real output is to foster price stability."

$$
\begin{gathered}
\text { - Gary H. Stern, President, } \\
\text { Federal Reserve Bank } \\
\text { of Minneapolis }
\end{gathered}
$$

"I think we all agree that the goal of monetary policy is to promote maximum sustainable growth over time...But just as important, and consistent with this goal, the Federal Reserve must work toward ensuring an environment of price stability."

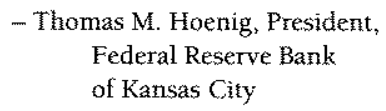

"...in the long rut the most significant contribution we can make to economic growth is by providing a low-inflation environment, and we have made progress in that area..."

$$
\begin{gathered}
\text { - Robert T. Parry, President, } \\
\text { Federal Reserve Bank } \\
\text { of San Francisco }
\end{gathered}
$$




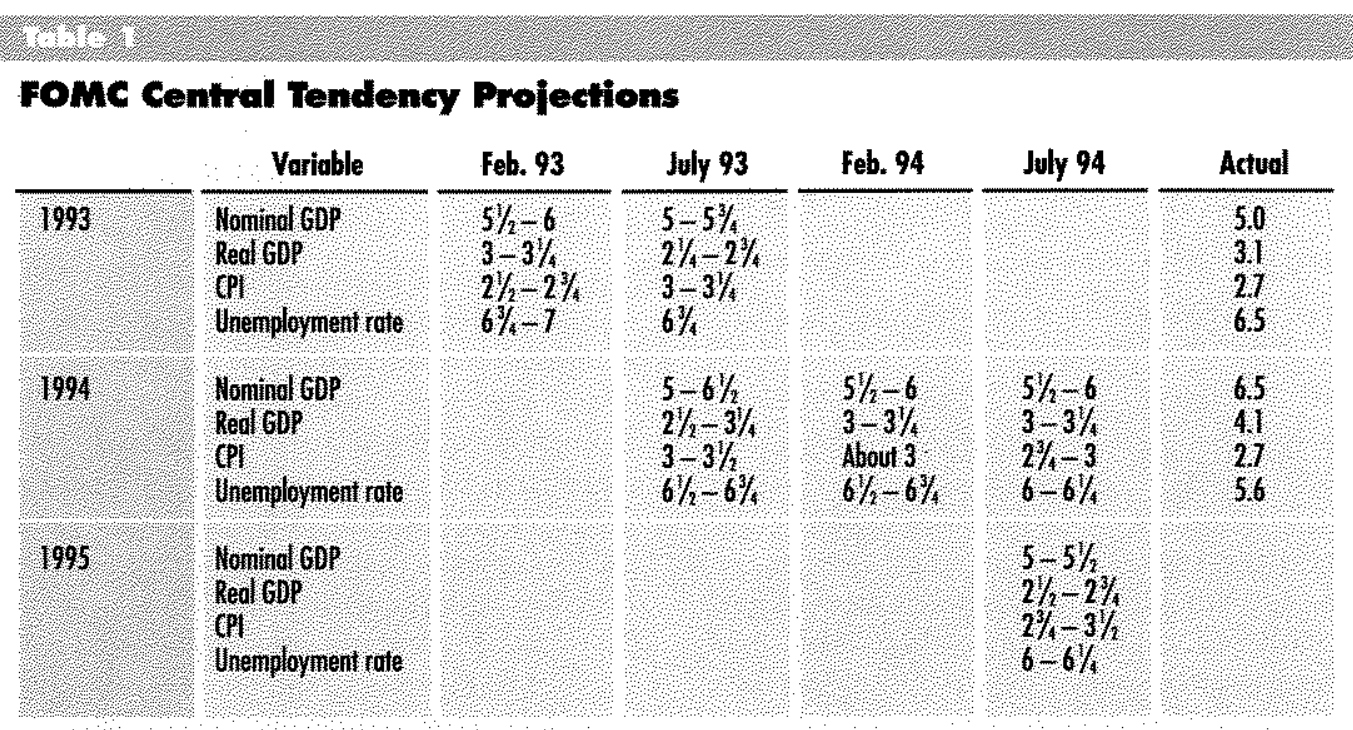

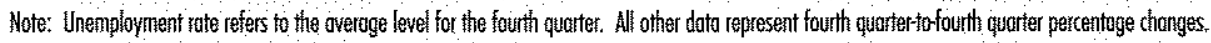

icant for economic and financial planning,"

However, many questions remain unresolved: What price index should be used for measurement? What rate of inflation corresponds to "price stability"? Should the Fed pursue objectives stated in terms of price levels or inflation rates? What operating procedures should be used to achieve the objective? What is the relevant time frame for achieving and maintaining price stability?

The emphasis on the benefits of longrun price stability suggests the potential efficacy of establishing long-run objectives for monetary policy. Under the present structure of policy formulation, the only quantitative method of communicating long-term expectations regarding the objectives of poli$c y$ is the bi-annual economic projections of the Committee, which are presented by the Chairman of the Board of Governors in each of the Humphrey-Hawkins reports to Congress. Table 1 reports the central tendency measures of these projections reported in 1993 and 1994. Note that these projections extend only 12 to 18 months. More importantly, it is unclear how the forecasts submitted by FOMC members incorporate anticipated monetary policy actions. Tinsley and others (1981) refer to the nature of these projections as "economic weather forecasts with provisions for cloudseeding." To the extent that the Fed's policy actions effect economic outcomes over this time horizon, the distinction between Committee members' expectations and objectives are somewhat unclear in these projections.

The notion of price stability as the ultimate goal of monetary policy and the recognition of the importance of long-term planning horizons have led some to advocate the introduction of some form of explicit long. range price level or inflation target to the monetary policy process. ${ }^{1 "}$ Recent policy reforms in New Zealand, Canada and Great Britain have moved in this direction, with apparent success to date. Advocates of such a policy for the United States emphasize the importance of credibility in monetary policy; that is, individuals and businesses are more likely to have faith in the Fed's ability to maintain price stability when there is a clear commitment to a specific objective."

Indeed, the importance of inflation expectations and the role of Fed credibility in the formation of those expectations are issues which have been emphasized in recent statements by Chairman Greenspan: "The effects of policy on the economy critically depend on how market participants react to Federal Reserve actions as well as on expectations of our future actions." As an example of the importance of expectations, Greenspan has suggested that a significant feature of the economy's slow emergence from the 1990-91
${ }^{3}$ Stotenent before the Committee an Bonking, Housing, and Urban Aftoirs, I.S. Senote, Febroany 19 , 1993. Fedend Reserve Bulletin (Ap;i 1993, p. 300)

See, for expmple, 1994 Amual Report, Fetereril Reserve Bonk of St. Latis. For on extingle ol o specific opercitiond plan for ochieving price stabilition, see Govin and Stockrian (1992).

"See, for example, Angell (1994) and loodan (1993).

${ }^{12}$ Statement before the Committee on Banking, Housing, and Ution Affoirs, U.S. Sentito, Feblutury 19, 1993. Federol Reserve Qubletin (AตAl 1993, B. 293). 


\begin{tabular}{|c|c|c|c|c|}
\hline \multicolumn{5}{|c|}{ Monetary Aggregate Objectives } \\
\hline \multirow[b]{2}{*}{ Date of Meeting } & \multicolumn{4}{|c|}{ Ranges (percentuge growth rotes) } \\
\hline & Torget Period & $M 2$ & M3 & Debt \\
\hline Feb. 23,1993 & $1992: 04-1993.04$ & 2106 & $1 / 2104 / 2$ & $4 / 2108 \%$ \\
\hline $114,67,1993$ & $\begin{array}{l}199204-1993: 04 \\
1993: 04-1994,04\end{array}$ & 1105 & $\begin{array}{l}0104 \\
0104\end{array}$ & $\begin{array}{l}4 \text { to } 8 \\
4 \text { to } 8\end{array}$ \\
\hline Tet, 22,1994 & $1993: 04-109404$ & 1105 & 0104 & 4 to 8 \\
\hline $14,20,1994$ & $\begin{array}{l}1993: 04-1994,04 \\
1994: 04-199504\end{array}$ & 1105 & $\begin{array}{l}0.14 \\
0104\end{array}$ & $\begin{array}{l}4,08 \\
3107\end{array}$ \\
\hline
\end{tabular}

recession was a need to restructure balance sheets, which in turn was partly attributable to inflation expectations: "...households and businesses apparently were skeptical that inflation would continue to decline and...may even have expected it to rebound. As a consequence, many may have shaped their investment decisions importantly based on expectations of inflation-induced appreciation of asset prices rather than on more fundamental economic considerations." 13

The idea that monetary policy should be charged with a single specific objective of price stability is not new. In 1989, Representative Steven Neal, D.-North Carolina, introduced legislation which would have mandated such a framework. At the time, the Neal proposal was met by favorable reactions from Chairman Greenspan and other FOMC members. More recently, Senator Connie Mack, R.-Florida, has indicated his intention to introduce legislation in 1995 for the purpose of modifying the HumphreyHawkins framework to eliminate references to employment and interest rate objectives, and to direct the Federal Reserve to limit CPI inflation to less than 2 percent per year. Chairman Greenspan has tesponded that he favors such legislation in principle, but has demurred on the issue of a numerical objective: "I have always argued that it would be useful for us...to be required to focus crucially, if not solely, on domestic price inflation... [but] I would be more inclined to go to a more general type of requirement for the central bank...." "is

The issue of whether to charge the Federal Reserve with a specific long-run price stability mandate is likely to remain as one of the crucial issues in monetary policy in 1995 and beyond.

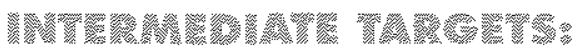

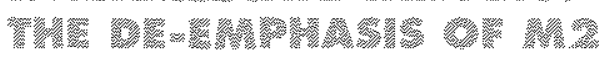

Perhaps the most fundamental modification to the intermediate targeting strategy witnessed over the past two years has been the continuing de-emphasis of the monetary targets as operational objectives. This is not to say that the aggregates are now disregarded altogether as indicators of policy, but rather that the prominence they once held in discussions of policy has diminished significantly.

Table 2 reports the ranges speciffed by the FOMC for money and credit growth in 1993 and 1994, and Figure 2 displays actual measures of the monetary aggregates relative to these target ranges. Despite the lessened emphasis on attaining monetary aggregate targets as a policy objective (discussed further below), the aggregates finished both years within the specified growth ranges. ${ }^{15}$

There is good reason to consider measures of the money stock as important indicators of the thrust of monetary policy. Both theoretically and empirically, the growth rate of money and the rate of inflation are known to be closely related-at least over long periods. This relationship can be clearly observed in comparisons of inflation rates and money growth rates across countries, and consideration of trends within a single country over extended periods of time. ${ }^{16}$ Over shorter time horizons, however, the relationship is much less apparent. This is at least partly attributable to the fact that measured monetary aggregates are, at best, an approximation of economists" conceptual notion of "money." From month to month or quarter to quarter, substitution among various assets often makes the growth rates of the aggregates difficult to interpret. Moreover, the rapid pace of financial innovation in recent years has changed the nature of the aggregates, further complicating their interpretation.

The FOMC began to consider monetary aggregates as operational objectives of policy explicitly in its directives in $1970 . "$ The status of the aggregates took on more prominence over the years, and their role as intermediate 


\section{Monetary Aggregates}
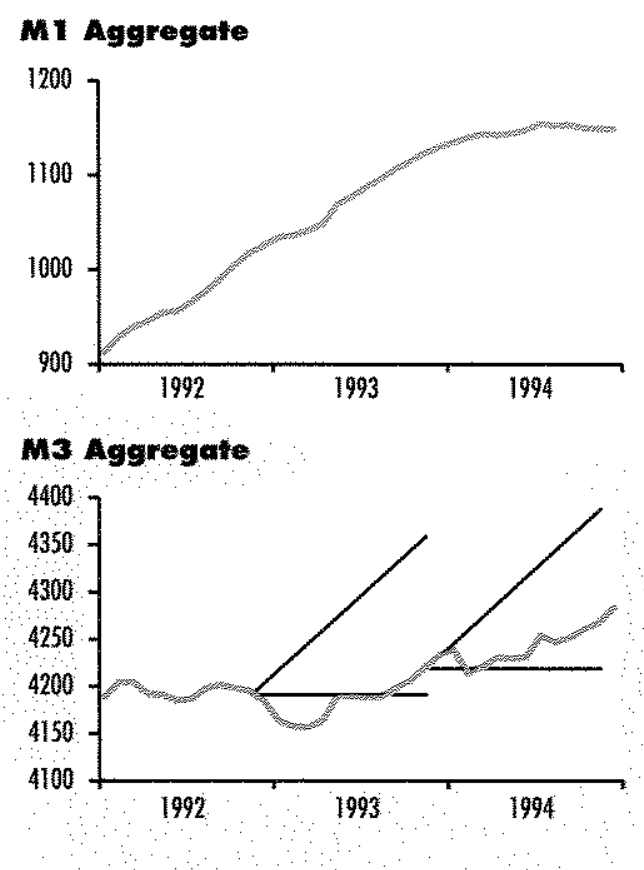

targets was written into the congressional mandates beginning with House Concurrent Resolution 133 in 1975 and later in the 1978 Humphrey-Hawkins legislation. The use of monetary aggregates as intermediate targets in the United States reached a high point during the period from October 1979 until the autumn of 1982, when the FOMC placed greater emphasis on monetary growth in an effort to establish a credible policy of halting and reversing the rising trend of inflation. While both $\mathrm{ML}$ and $\mathrm{M} 2$ were cited as operational objectives, primary attention at the time was focused on the narrow aggregate M1. By the mid-1980s, however, the relationship of $\mathrm{Ml}$ to overall economic activity had apparently changed so much that it seemed less desirable as an intermediate target. In fact, reference to $\mathrm{Ml}$ was removed from the FOMC's policy directives starting with the October 1982 meeting, and the Committee stopped reporting annual growth objectives for MI in 1987. ${ }^{18}$

The issue of which monetary aggregate is appropriate for guiding policy has a long and controversial history in discussions of

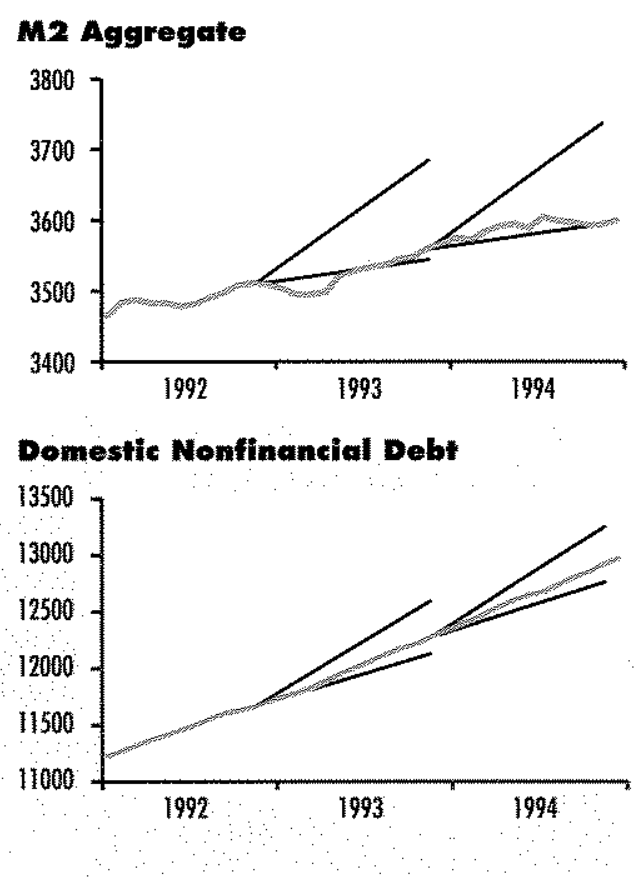

monetary policy. Some economists, emphasizing the transactions role of money, have typically favored narrower measures such as Ml. Others, who stress the additional role of money as a store of value, suggest that broader aggregates like $\mathrm{M} 2$ are more appropriate as indicators of available purchasing power. While such theoretical considerations are certainly considered by policymakers, the FOMC's choice of intermediate target has typically appeared to be guided more by observations on the consistency and stability of relationships between the aggregates and economic activity.

In the absence of reliable information from $\mathrm{Ml}$ after the mid-1980s, the broader aggregate M2 naturally took on greater prominence. In the early 1990 s, however, the relationship between $\mathrm{M} 2$ and overall economic activity also began to show signs of deterioration. One way of summarizing this relationship is to consider the velocity of $\mathrm{M} 2$ - the ratio of the total dollar value of GDP to M2. Figure 3 illustrates the historical behavior of $\mathrm{M} 2$ velocity. Until recently, this measure has shown little tendency to display
${ }^{18}$ A disesssien of the problems encosntered with $M I$ is beyend the scope of this article. Some of these issles are explored in Stone find Thernton (1987). 


\section{2.}

Velocity and Opportunity Cost of M2

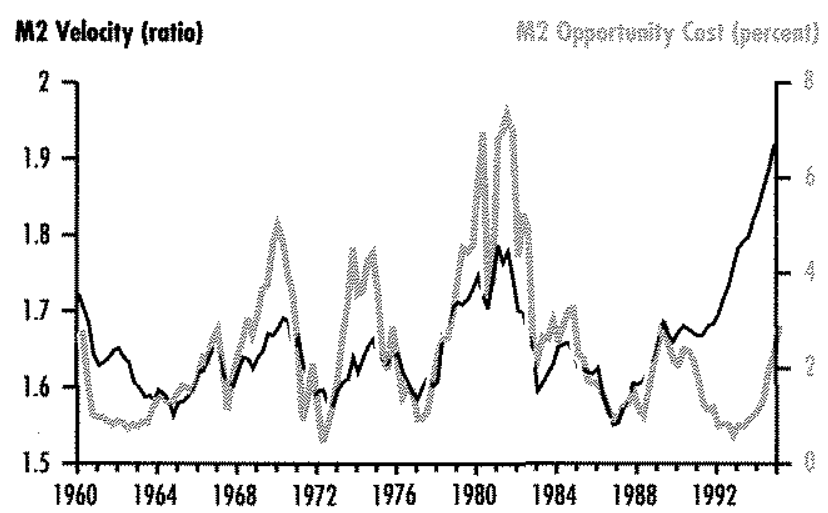

${ }^{19}$ The FomC's discussion of the Feinmenn and Poffer study was repatted by the Americon Banker (see Cumnins, 1992).

2l Statement before the Committee on Banking, Housing, and Uthan Afforis, U.S. Sente (t) 22,1993, p. 34). any trend rate of growth, fluctuating around a constant value of approximately 1.65.

As shown in Figure 3, much of the variability of M2 velocity around its trend can be related to a measure of opportunity cost. The opportunity cost measure illustrated in Figure 3 is defined as the difference between the interest rate on three-month Treasury bills (considered to be an alternative to holding M2 assets) and a weighted average of the rates of return on assets included in $\mathrm{M} 2$. When the opportunity cost of holding $\mathrm{M} 2$ is high (that is, when the teturn on M2-type assets is relatively low), the growth rate of M2 tends to be lower than it otherwise would be as people take advantage of other, higher-yielding alternatives. Hence, the velocity of $\mathrm{M} 2$ tends to rise above its trend.

It is clear from Figure 3 that this relationship has recently departed from its typical historical pattern. While the measured opportunity cost of holding M2 has been quite low during the early 1990s, M2 growth has been uncharacteristically slow so that velocity has risen far above its average level.

As the breakdown of this relationship became apparent in the early 1990s, Federal Reserve officials searched for explanations. In a staff study presented to the FOMC at the meeting of November 17, 1992, Feinman and Porter (1992) suggested one possible explanation which seemed to account for some of the anomalous behavior of $\mathrm{M} 2$ velocity: They pointed out that the use of the three-month T-bill yield to measure opportunity cost may not fully capture the range of alternative yields relevant to the public's demand for $\mathrm{M} 2$, Experimenting with a broader range of opportunity cost measures, Feinman and Porter found that using loan rates and longer-term Treasury yields helped to explain the behavior of $\mathrm{M} 2$ velocity in the 1980s and 1990s. This expla nation seemed particularly relevant given the steepness of the yield curve that prevailed in 1992: If longer-term assets were, in fact, good substitutes for the components of $\mathrm{M} 2$, then the relatively high rates of return on long-term instruments may well have been attracting funds out of $\mathrm{M} 2$, depressing its growth rate.

Although this insight helped to account for unusually slow M2 growth to some extent, its explanatory power was apparently insufficient to sustain FOMC members' confidence in $\mathrm{M} 2$ as an intermediate target beyond mid 1993 . In discussing the deemphasis of $\mathrm{M} 2$ at the Humphrey-Hawkins hearings in July 1993, Chairman Greenspan described how quickly this confidence had evaporated: "The evidence as of, say, the end of last year, would suggest that it was probably correct to assume that M2 was becoming increasingly faulty. Six months later, it's becoming extraordinarily persuasive."

As further observations became available, the yield curve explanation became even more untenable as a significant explanation for the rapid growth of $\mathrm{M} 2$ velocity. In particular, the sharp flattening of the yield curve in 1994 appeared to be associated with little if any slowdown in velocity growth.

Although the slow growth of M2 in recent years is not fully explicable, at least two additional transitory special factors have contributed to the weakness. First, the large decline in interest rates during 1991 and 1992 stimulated extensive refinancing of long-term debt, particularly mortgages. In the refnancing process, mortgage servicers tended to hold funds in highly liquid deposits prior to transferring the balances to investors holding the underlying mortgagebacked securities. The large volume of funds moving through liquid deposit accounts 
associated with this activity had the effect of boosting the meastured growth rate of the monetary aggregates. As this refinancing activity declined in 1994, the associated runoff of liquid funds tended to dampen monetary growth rates. ${ }^{21}$ This factor is clearly temporary in nature, and it is likely that inter-aggregate flows associated with refinancing activity had subsided by mid- 1994 .

A second possible factor contributing to uncharacteristically slow M2 growth is the recent surge in popularity of bond and equity muttal funds. Figure 4 illustrates net assets of these instruments over the past several years. A significant portion of these funds appeared to be flowing from time deposits and money market mutual funds, which are both included in M2. Figure 4 illustrates the correspondence between the recent period of sharply rising M2 velocity and the period of dramatic mutual fund growth. To the extent that portfolio shifts from $\mathrm{M} 2$ assets into mutual funds has accounted for the anomalous behavior of M2 growth, an aggregate that includes mutual funds along with M2 assets (called $\mathrm{M} 2$ Plus) could potentially perform better than the conventional M2 definition. Researchers at the Board of Governors investigated this possibility, and the matter came up for discussion at the FOMC meeting of July $6-7,1993$. This research suggested that although the velocity of M2 Plus was somewhat less anomalous than that of $\mathrm{M} 2$, the inclusion of mutual funds did not fuly eliminate the recent velocity puzzle. ${ }^{22}$ Accordingly, the minutes of the FOMC report that "after examining the properties of this measure and reviewing its past behavior in relation to key indicators of economic performance, the members concluded that it would not enhance the formulation or implementation of monetary policy, at least at this point." ${ }^{23}$

Subsequent experience appeared to have borne out the Committee's assessment. As illustrated in Figure 4, llows into thutual funds have slowed dramatically during 1994 as interest rates have risen. M2 growth, however, has remained uncharacteristically slow, with its velocity reaching record highs toward the end of the year.

In recognition of these unusual factors

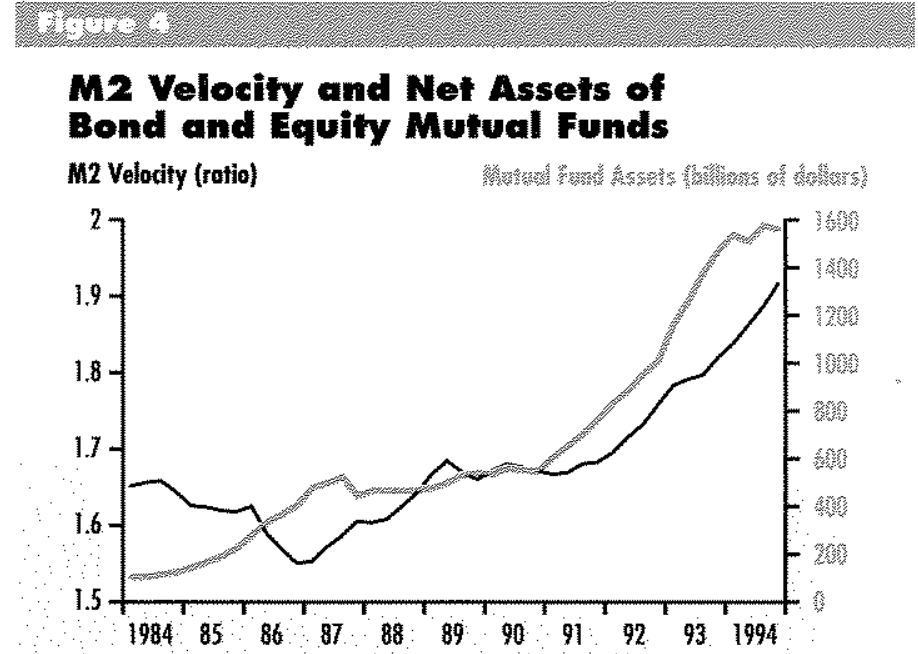

affecting the growth rate of the monetary aggregates, the FOMC lowered its growth objectives for M2 and M3 at its July, 1993 meeting (see Table 2). In his subsequent report to Congress, Chairman Greenspan indicated that the Committee had also decided to de-emphasize its consideration of M2 as a policy target: "At least for the time being, M2 has been downgraded as a reliable indicator of frnancial conditions in the economy, and no single variable has yet been identified to take its place."2t

The lack of any particular measure to fill the role previously played by monetary aggregates has fundamentally altered the ostensible control strategy of the intermediate targeting approach, with members of the Committee left to rely on "ongoing assessments of the totality of incoming information and appraisals of the probable outcomes and risks associated with alternative policies." ${ }^{25}$ More importantly, the ability of policymakers to communicate long-term policy intentions is greatly diminished by the absence of meaningful monetary targets. Although monetary targets have never been the sole guide for FOMC policy decisions, they did provide a useful framework for assessing short-run policy adjustments in a context of longer-run objectives. In the absence of intermediate targets, public attention has become more focused on short-term adjustment in the federal funds rate and discount rate.

\footnotetext{
2) Se Anderson (1993).

2" See Collins and Edwards (1994) and Orphanides, Reid and Smoll (1994).

23 Minutes of the Federal Open Maket Committee Heeting of July 67 , 1993. Fedord Raserve Bulletin (Octover 1993, 99.9445 ).

${ }^{24}$ Stitement before the 5 ubrammittee on Econanic Growth and Cedit Formation of the Conminitte on Enonking, Finconce ond Uthon Affoiss, US. House of Representotutives, July 20, 1993. Federal Reserve Bulletin (September 1993, p. 852).

${ }^{25}$ Statement by Alan Greenspan, Chaimen, Federd Reserve Bonard, betose the Subcommittee on Economic Growth and Credit Formation of the Cornenithe on Bonking, Finante ond Uitban Affuis, U.S. House of Regresentutives, Februan 22, 1994. Fedorot Reserve Bullefin (Apri) 1994, p. 304).
} 
FOMC Directives and Measures of Monetary Policy Stance

\begin{tabular}{|c|c|c|c|c|c|c|}
\hline \multirow[b]{2}{*}{ Meefilg } & \multirow[b]{2}{*}{$\begin{array}{l}\text { Directive for } \\
\text { Beserve Pressure }\end{array}$} & \multicolumn{2}{|c|}{ Intermeeting Sfance Toward: } & \multicolumn{3}{|c|}{ Result from Change it Reserve Pressure.. } \\
\hline & & Lesser Restrein & $\begin{array}{l}\text { Gredter } \\
\text { Restruine }\end{array}$ & Date of Change: & Funds rute & Discoun fole \\
\hline \multicolumn{7}{|l|}{1993} \\
\hline te6.23 & maintain & would: & would & $\mathrm{N} / \mathrm{A}$ & 3.00 & 3.00 \\
\hline Mo. 23 & maintain: & would & woutd & $N / A$ & 3.00 & 300 \\
\hline Hay 18 & maintain & night & waudd & $\mathrm{N} / \mathrm{A}$ & 300 & 3.00 \\
\hline 10167 & mointein & might & would & $N / A$ & 300 & 3.00 \\
\hline Auso 17 & maintain & night & might & $N / A$ & 300 & 3.00 \\
\hline Seq 21 & mointein & might: & miglie & $N / A$ & 300 & 300 \\
\hline Nor 16 & Bainitain & might: & might & $N / A$ & 300 & 300 \\
\hline 00.21 & mantain & might & right & $N / A$ & 300 & 300 \\
\hline \multicolumn{7}{|l|}{1994} \\
\hline Eef, 34 & fncrease slightfy & might: & might & $2 / 4 / 94$ & 3.25 & 300 \\
\hline \multirow[t]{2}{*}{ Mar. 22} & hicrease slighty & might & niglit & $3 / 22 / 948$ & 350 & 300 \\
\hline & & & & $4 / 18 / 94$ & 375 & 3.00 \\
\hline Moy 17 & increase somewhot & might & might & $5 / 17 / 94$ & 425 & 3.50 \\
\hline 101.56 & mantata & might & would & $N / A$ & 425 & 3.50 \\
\hline Aug, 16 & ncreuse somewhul & would & would & $8 / 16 / 94$ & 475 & 400 \\
\hline Sep 77 & maintain & might & would & $W / A$ & 475 & 400 \\
\hline Nov 15 & increase significantly & would & would & $1 / / 15 / 94$ & 550 & 475 \\
\hline 00120 & niantrin & might & would & $N / A$ & 550 & 475 \\
\hline
\end{tabular}

* Federal funds rote expected to be consistent with desired reserve restraint.

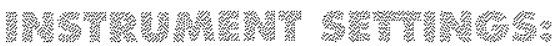

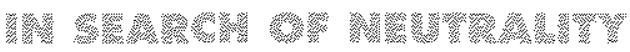

Although developments in the evolution of the FOMC's policy framework described above are significant, it is the meeting-to-meeting actions of the Committee and their effect on short-term interest rates which have attracted the attention of the public. From 1989 through 1992, the FOMC endorsed a policy of easing reserve restraint, permitting rapid growth of bank reserves and facilitating 25 distinct declines in short-term interest rates, cumulating in nearly a 7 percentage point drop from previous peaks. During 1993, the Committee called for "maintaining the existing degree of pressure on reserve positions" at each of its meetings, and the federal funds rate remained fairly constant at around 3 percent. In 1994 , on the other hand, the Fed announced actions to increase reserve pressure on six separate occasions, with the cumulative effect of these actions reflected in an increase of around $2 \frac{1}{2}$ percentage points in the federal funds rate. Table 3 summarizes the actions taken by the FOMC at its meetings over the 1993-94 period. The appendix to this article summarizes the discussions that took place at those meetings.

As is always the case when the FOMC's policy decisions are associated with interest rate increases, the Fed has been criticized in 1994 for hampering the economy by pursuing overly "tight" monetary policy. However, it is not clear that the policy moves taken in 1994 should be considered particularly restrictive. Rather, the stated intentions of the Committee have been to move the stance of policy from one of "accommodation" to "a more neutral posture."

The steady policy pursued in 1993 was recognized by Committee members as being purposefully accommodative. Lacking any 


\section{MEMBERS OF THE FOMC IN 1993 AND 1994}

At any given time, the Federal Open Market Committee consists of 12 voting members The Committee includes all seven members of the Board of Governors of the Federal Reserve System, as well as five of the 12 presidents of the regional Federal Reserve banks. Reflecting the importance of the Federal Reserve Bank of New York in policy implementation, the president of that Reserve Bank is always a voting member and is, in fact, elected as Vice Chairman of the Conmittee (the Chairman of the Board of Governors is elected as Chairman of the FOMC). The remaining four positions rotate among the presidents of the other 11 Federal Reserve banks. Although only a limited number of Federal Reserve Bank presidents are voting members of the Committee, all 12 attend the meetings and participate in the discussions.

In addition to the usual rotation of Federal Reserve Bank presidents as voting members of the Committee, the Committees composition in 1993 and 1994 changed due to changes in the membership of the Board of Governors and the presidency of the New York Fed. Listed below are the voting members of the FOMC in 1993 and 1994.

1993

Alon Greenspan

Chaiman, Bourd of Governors

E. Gerotd Corrigan/Willian J. McDonough * President, Federal Reserve Bank of New York

Dovid W. Mullins, Jr. Vite Chairman, Board of Governors

Wayae D. Angell mentier, Bourd of Governors

Johin P. LoWare

inember Bourd of Governors

Lowrence B. Lindsey

membier, Boand of Governors

Susan M. Phillips

member, Bourd of Governors

Edward W. Kelley, J.

member, Boord of Governors

Edward G. Boehne

President, Federd Reserve Bank of Philadelphio

Silos Keehn

President, Federal Reserve Benk of Chicogo

Robert D. McTeer, Jr.

President, Feteral Reserye Bank of Dallos

Gary H. Stern

President, Federal Reserve Bonk of Minnegpolis
1994

\begin{tabular}{|c|}
\hline $\begin{array}{l}\text { Alan Greenspan } \\
\text { Chairman, Bourd of Governots }\end{array}$ \\
\hline $\begin{array}{l}\text { Willian J. McDonough } \\
\text { President, Federal Reserve Boak of New York }\end{array}$ \\
\hline $\begin{array}{l}\text { Alan S. Bindert } \\
\text { Vice Chairman, Board of Governors }\end{array}$ \\
\hline $\begin{array}{l}\text { Jonet L Yellen } \\
\text { member, Bourd of Govenors }\end{array}$ \\
\hline $\begin{array}{l}\text { Johin P. LaWare } \\
\text { nember, Bord of Governors }\end{array}$ \\
\hline $\begin{array}{l}\text { Lawrence B. Lindsey } \\
\text { member, Borrd of Governors }\end{array}$ \\
\hline $\begin{array}{l}\text { Susan M. Phillips } \\
\text { nember, Booud of Governors }\end{array}$ \\
\hline $\begin{array}{l}\text { Edward W. Kelley, J. } \\
\text { nember, Coard of Governołs }\end{array}$ \\
\hline $\begin{array}{l}\text { J. Alfred Brooddus, Jr. } \\
\text { President, Federal Reserve Bank of Richmend }\end{array}$ \\
\hline $\begin{array}{l}\text { Robert P. Forresial } \\
\text { President, Federal Reserve Bank of Allanta }\end{array}$ \\
\hline $\begin{array}{l}\text { Jerry L. Jordan } \\
\text { President, Federal Reserve Bonk of Cleveland }\end{array}$ \\
\hline $\begin{array}{l}\text { Robert T. Parry } \\
\text { President, Federal Reserve Benk of Son Frantisto }\end{array}$ \\
\hline
\end{tabular}

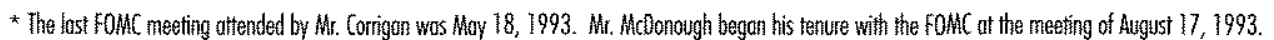

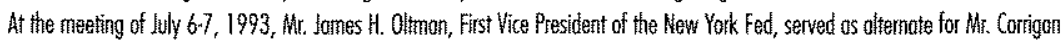

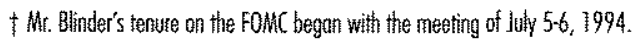

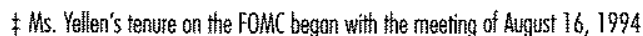


${ }^{26}$ Stdetement by Alan Geemssgen, Choimon, Federal Reserve Boond, before the Conthititeet on Banking, Hausing, and IItacn Affairs, U.S. Senote, 沎y 20, 1994. Federal Reserve Buhlotin (Septenter 1994, pp. 793.4 )

${ }^{27}$ Minutes of the Feterd Open Makel Committer theeting of loly 6-7, 1993. Foderol Reserve Bullotin (0ctober 1993, p. 946)

28 Stotement before the Joint Economic Comnittee, United States Congress, Inawary 31, 1994. Fedeal Reserve Bullefin (Whorh 1994, p. 233).

${ }^{29}$ Minutes of the Federal Open Market Cormittee Meeing af Fobruon 3-4, 1994. Fedetal Reserve Bulletin (H, 19y 1994, p. 408)

29. Stelement by Alan Eteenspan, Choirnan, Federol Reserve Band, before the Connittee on Banking, Housing, and Uthan Affars, U.S. Sencte, Jity 20, 1994. Federit Reserve Bulletin (September 1994, p. 794).

${ }^{37}$ Minutes of the Federal Open Matiket Commites Meeting of Auggyss 16 , 1994. Federd Resenve Bulletin (November 1994, p. 996 )

${ }^{37}$ Statentent before the Conmitate on Banking, Hassing, and Utbon Affairs, U.S. Sencte, Fehunary 19, 1993. Fedegal Resarve Bullomin (Apil 1994, p. 294). clear guidance from the behavior of monetary aggregates, this characterization of policy was based on the observation that short-term interest rates remained extraordinarily low, particularly in relation to the underlying rate of inflation. With short-term interest rates and inflation both holding at about 3 percent, short-term real interest rates (inflation adjusted) were close to zero. The Committee members viewed the maintenance of such low levels of interest rates as being an unwise and unsustainable policy over the long run: ".., history strongly suggests that maintenance of real short-term rates at levels prevailing [in 1993] ultimately would have fueled inflationary pressures. ${ }^{36}$

This policy was maintained in an effort to alleviate a number of special factors which appeared to be inhibiting a strengthening of the economic recovery. In his testimony before Congress in February 1993, Greenspan cited a need for balance sheet restructuring by households and firms, difficult adjustments associated with business restructuring, and the contractionary effects of cuts in federal defense spending.

Throughout 1993, the members of the Committee were circumspect regarding the accommodative nature of policy. At both the May and July meetings, the Committee endorsed a policy which-although calling for no immediate change in the stance of policy-specifted a bias toward the possibility of increasing the degree of reserve restraint (see the appendix). The Minutes of the July meeting reveal that some members "commented that while the need for any policy adjustment during the period ahead seemed somewhat remote, the next policy move was more likely to be in the direction of some firming than toward easing." ${ }^{.27}$

At a hearing before the Joint Economic Committee of Congress in late January 1994 , Chairman Greenspan clearly indicated that a move toward greater reserve restraint was not a matter of if, but of when: "At some point, absent an unexpected and prolonged weakening of economic activity, we will need to move [short-term interest rates] to a more neutral stance."' At the next meeting of the FOMC, the first step in that direction was taken. Because this move was the first tightening of policy to be undertaken in some time, the Committee agreed to a proposal to have the Chairman announce the move. "The purpose of such an announcement, which would be a departure from past Committee practice, was to avotd any misinterpretation of the Committee's action and its purpose."29 (See the shaded insert titled "Policy Disclosure.")

As the year progressed, further increases in the degree of reserve pressure were undertaken on five additional occasions, three of which were accompanied by increases in the discount rate (see Table 3 and the appendix) The Committee proceeded with the tightening in this step-by-step manner in recognition of the difficulty of knowing precisely what trading range for the federal funds rate was appropriate: "...it is an open question whether our actions to date have been sufficient to head off infla tionary pressures and thus maintain favorable trends in the economy." 30

At the same time, Committee members expressed a desire to move decisively enough to head off emerging inflationary expectations. In the discussion surrounding the $1 / 2$ percentage point increase in the fed funds rate and discount rate taken on August 16, members noted that "a more decisive policy move might reduce the need for further tightening later... by helping to curb inflationary expectations more effectively. ${ }^{12}$

In fact, the objective of subduing inflationary expectations was a prominent consideration in the FOMC's policy deliberations in 1993 and 1994. One of the indicators used to discern these expectations is the slope of the yield curve, the steepness of which had been of concern to policymakers for some time. As early as February 1993, Greenspan had pointed out that "The steep slope of the yield curve and the expectations about future interest rates that the slope implies suggest that investors remain quite concerned about the possibility of higher inflation... ." ${ }^{32}$

Although conclusions about inflationary expectations embedded in the yield curve should be interpreted cautiously, the reaction of the term structure of interest rates to the policy moves taken in 1994 provides an interesting perspective on those events. As illustrated in Figure 5, the initial increases in short-term interest rates during 1994 were accompanied by shifts in the entire term 


\section{POLICY DISCLOSURE'}

Another issue with which the Committee grappled throughout 1993 and 1994 was the timing of, and extent to which, policy decisions should be announced to the public. Traditionally, the policy decisions of the FOMC have been closely guarded secrets, with minutes of each meeting issued only after the subsequent meeting had concluded (so that the current operational directive was never made public). The purpose of this confidentiality was to avoid the possibility of financial market instability in the wake of policy changes, as well as to give the FOMC more flexibility in the implementation of policy. This practice has always been controversial, and criticism of the Fed's traditional secrecy had recently intensified, particularly among some members of Congress. The FOMC reconsidered the disclosure issue during 1993, and experimented with announced policy changes during 1994.

The issue of public disclosure was discussed at the first FOMC meeting of 1993 , as the Committee considered a preliminary report of a subcommittee that had "been established to examine various issues relating to the release of information about Committee meetings and decisions? The mernbers agreed that the public should be fully informed about policy decisions, but expressed concern that "release of information should not be allowed to compromise the overriding objective of making and implementing the best possible decisions."

At the July $6-7,1993$ meeting the issue arose again in the context of media reports of the purported results of the May meeting before the Committee had made public any information about that meeting on that occasion, the members "agreed that particular care needed to be taken for some period before and after each of its meetings" to prevent leaks.

An extended discussion of alternatives for releasing detalled information on the deliberations of the Committee took place at the meeting of November 16, 1993. The Committee agreed to atthorize lightly edited transcripts of past meetings and to release the transcripts to the public five years after the meetings, subject to the redaction of especially sensitive materials?

The issue of public announcenents took on greater prominence at the first meeting of 1994, when the Conmittee decided to announce the short-term policy decision promptly after the meeting. The purpose of this announcement was to avoid any misinterpretation of the Committees action and its purpose. Because this would be the first tightening policy action. [since early 1989; ] it was likely to attract considerable attention ". Committee members were careful to point out that they did not consider this announcement to set any precedents for future announcements.

Nevertheless, each of the subsequent changes in policy during 1994 were followed by a brief aninouncement at the conclusion of the meeting. The announcements were generally brief, but gave qualitative information regarding the nature of the policy decisions, and also gave an indication as to the magnitude of federal funds rate alterations that would be associated with the changes. For instance, a statement following the meeting of August 16, 1994, combined the announcement of a $1 / 2$ percentage point increase in the discount rate with an announcement that the FOMC had decided that "this increase would be allowed to show through completely into interest rates in reserve markets".

At the meeting of July 5-6, 1994, the Committee addressed the issue of announcing the outcome of a decision to leave policy unchanged. The members agreed to "provide a brief and informal indication that the meeting had ended and that there would be no further announcements." A similar announcement of "no further announcements" was released at the conclusion of the September and December meetings. In early 1995, the Committee endorsed the practice of having the Chatrman issue a brief statement describing policy actions after each meeting as a regular practice. 


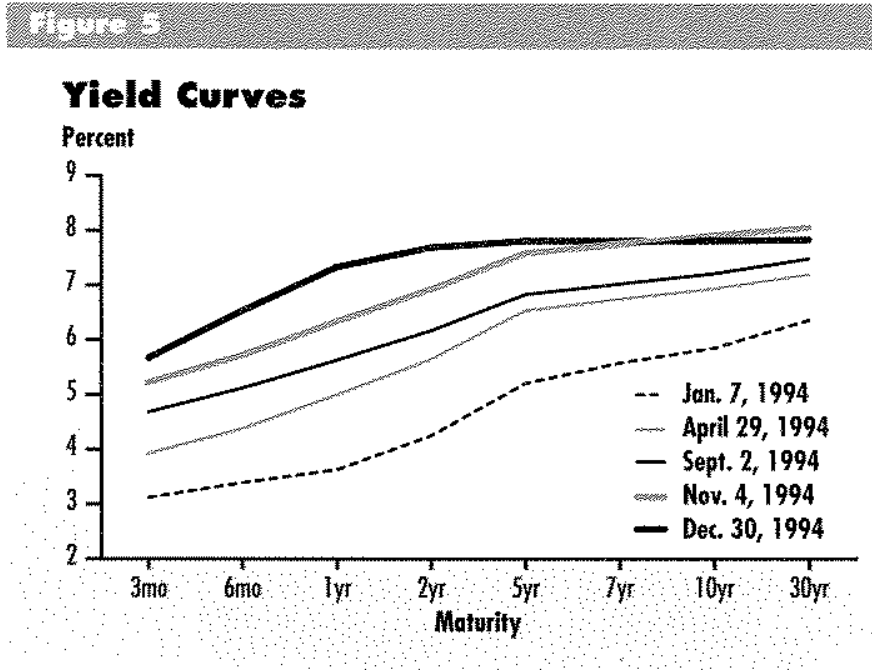

structure. By April 29, after the first three $3 / 4$ point increases in the federal funds rate, the three-month and 30-year yields had risen by roughly equivalent magnitudes. Yields on intermediate-term maturities had risen by somewhat greater amounts, suggesting that investors expected that further increases in short-term tates were likely in the near future. By early November, the yield curve had shifted further, but with the spread between long-term and short-term yields narrowing: From the beginning of the year, three-month yields had risen by more than 2 percentage points, while the yields on 30-year bonds had risen about $1 \%$ percentage points. The response of the term structure to the 75 basis point increase in the federal funds rate on November 15 is even more striking. Longer maturity yields actually declined following that change, and continued to trend downward until the end of the year. This unustal pattern of rate movements-and the flattening of the yield curve that they represent-suggest that by the end of 1994, inflationary expectations were responding favorably to the cumulative impact of the FOMC's policy moves.

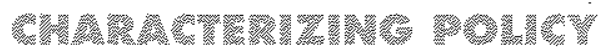

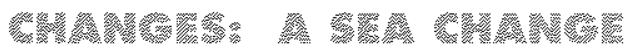

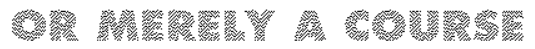

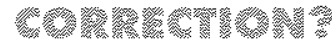

As described in the previous section, the FOMC acted to "increase the degree of pressure on reserve positions" on six separate occasions in 1994, after leaving policy unchanged over the course of 1993. The most readily observable response to these developments has been the rise in short-term interest rates. It is often asserted that the Fed is responsible for pushing short-term interest rates higher, and that both the intent and the effect of these rate increases is to slow economic growth. On the other hand, interest rates teflect the balance of supply and demand in credit markets. Hence, when economic activity is accelerating and credit demands rising, market forces should be expected to push interest rates higher and the Fed's actions in the market for bank reserves could be interpreted as allowing those market forces to work. For economists evaluating the impact of the FOMC's policy decisions, the distinction between these two perspectives is of great importance. Is the Fed actively attempting to manipulate the course of the economy, or merely adjusting the settings of its policy instruments to meet evolving economic conditions?

One can take several approaches to addressing this question, none of which is entirely satisfactory. Perhaps the simplest approach is to examine the behavior of the raw data summarizing FOMC policy actions-the instruments or proximate targets of policy. Figure 6 illustrates the recent behavior of the federal funds rate, the most widely monitored measure of the stance of monetary policy. After declining from 1989 through 1992, the funds rate remained fairly stable at around 3 percent during 1993 and then graduatly rose to 5.5 percent during 1994 . It is the increase in this key short-term rate which most observers point to as a measure of the deliberate tightening of monetary policy in 1994.

However, a perusal of the behavior of longer-term interest rates illustrated in Figure 7 shows that many interest rates began to rise before the FOMCs first policy adjustment in February 1994. Long-term interest rates reached their lows during September and October of 1993, and rose through most of 1994. Figure 8 suggests a reason for the upward pressure on rates: Demand for credit, represented by the volume of commercial bank loans, picked up dramatically during the latter part of 1993. Taking these devel- 
opments into consideration, the FOMCs policy approach in 1994 might be more accurately described as one of not preventing a natural increase in interest rates, rather than one of deiberately pushing rates higher.

Another raw measure of the thrust of monetary poltcy is the growth rate of nonborrowed reserves. Although the FOMC itself does not presently define its policies in terms of reserve growth, the supply of nonborrowed reserves is directly affected by the Fed's open market operations. Changes in the demand for reserves largely reflects luctuations of the checkable deposits component of M1. As illustrated in Figure 9, a reserve-based view suggests that policy in 1993 was not as static as suggested by the stability of the fed funds rate. Rather, to maintain a stable funds rate, reserve growth was allowed to fluctuate rather widely throughout the year. Figure 9 also shows that by recent historical standards, the average growth rate of reserves in 1993 was quite rapid. Reserve growth dropped off sharply during 1994, turning negative in the latter part of the year.

Economists who take a rarrow-money approach view the rapid growth in nonborrowed reserves, the monetary base and $\mathrm{Ml}$ in 1993 as suggesting that policy was not neutral. Such a view is based on the notion that rapid growth in money will, with a lag, cause rapid growth in aggregate demand. According to this view, policy might be characterized as being highly expansionary in 1992 and 1993, with an abrupt reversal in 1994. Such stopand - go policy, illustrated in Figure 9 by wide fluctuations in the growth of nonborrowed reserves, is thought by some to exacerbate the business cycle.

Given these somewhat disparate indications from the proximate targets of monetary policy and the ambiguity of distinguishing between deliberate changes in the stance of policy from endogenous responses to broader economic developments, economists have sought to develop more specific methods of identifying major Federal Reserve policy shifts and distinguishing them from minor policy adjustments. One approach, pioneered by Friedman and Schwartz (1963) and recently extended by Romer and Romer (1989), is the "narrative approach." This approach seeks to
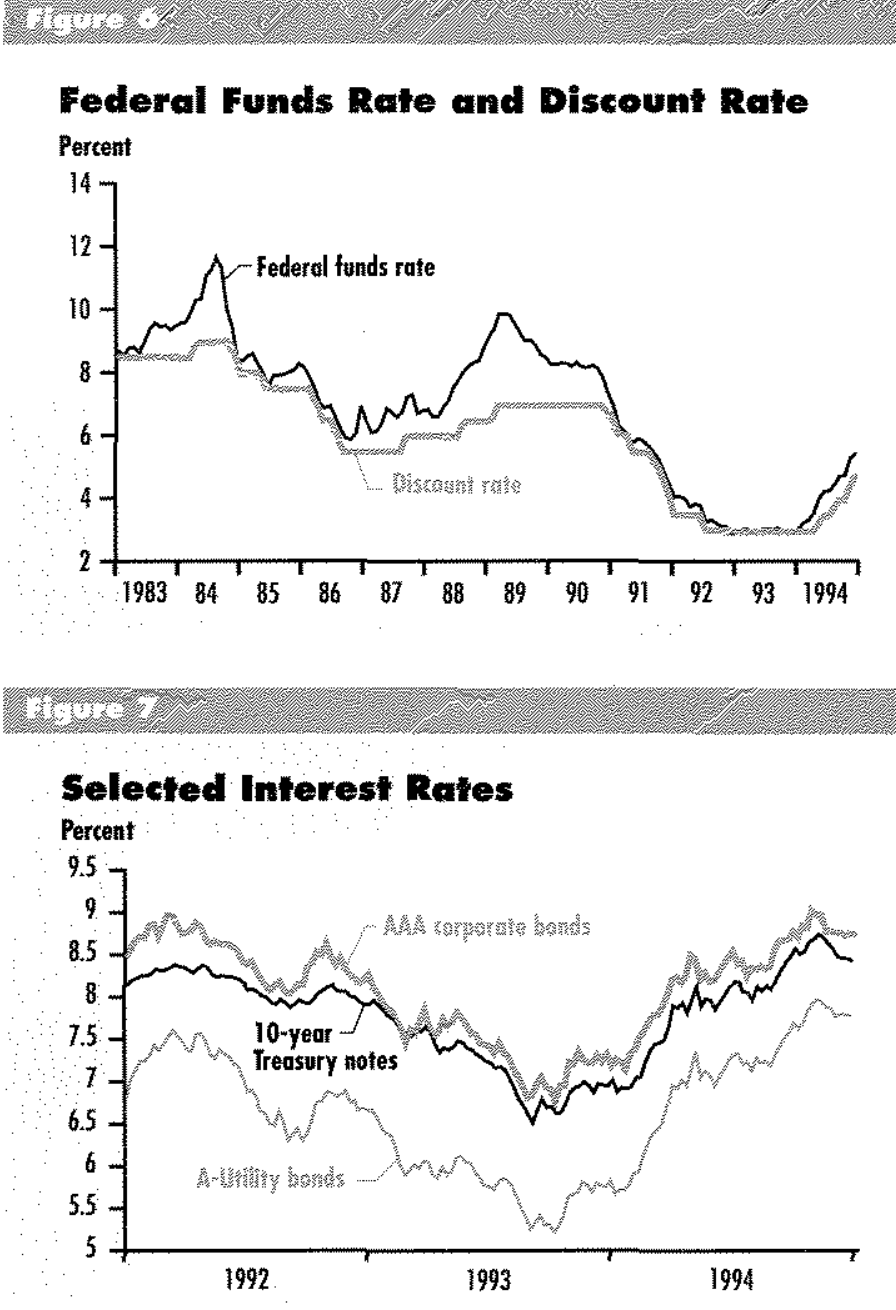

identify discrete shifts in policy by examining qualitative measures of policy: for instance, the statements issued by the FOMC and its members. Romer and Romer developed criteria for distinguishing turning points in policy, which identify a policy "shock" as a situation "in which the Federal Reserve attempted to exert a contractionary inluence on the economy in order to reduce inflation." ${ }^{33}$ These events can be thought of as deliberate changes in the overall thrust of policy.

Although many observers might characterize the FOMCs policy decisions in 1994 as constituting such a policy shock, it is hard to justify this conclusion using the Romer and Romer criteria. In particular, the Romers exclude from their classification episodes in which the FOMC acted to prevent the emer-
${ }^{9} 3$ Roner and Rorner $(1989$, p. 134). 


\section{REVIEW}

MARCH/APRIL 109

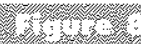

Commercial Bank Loans

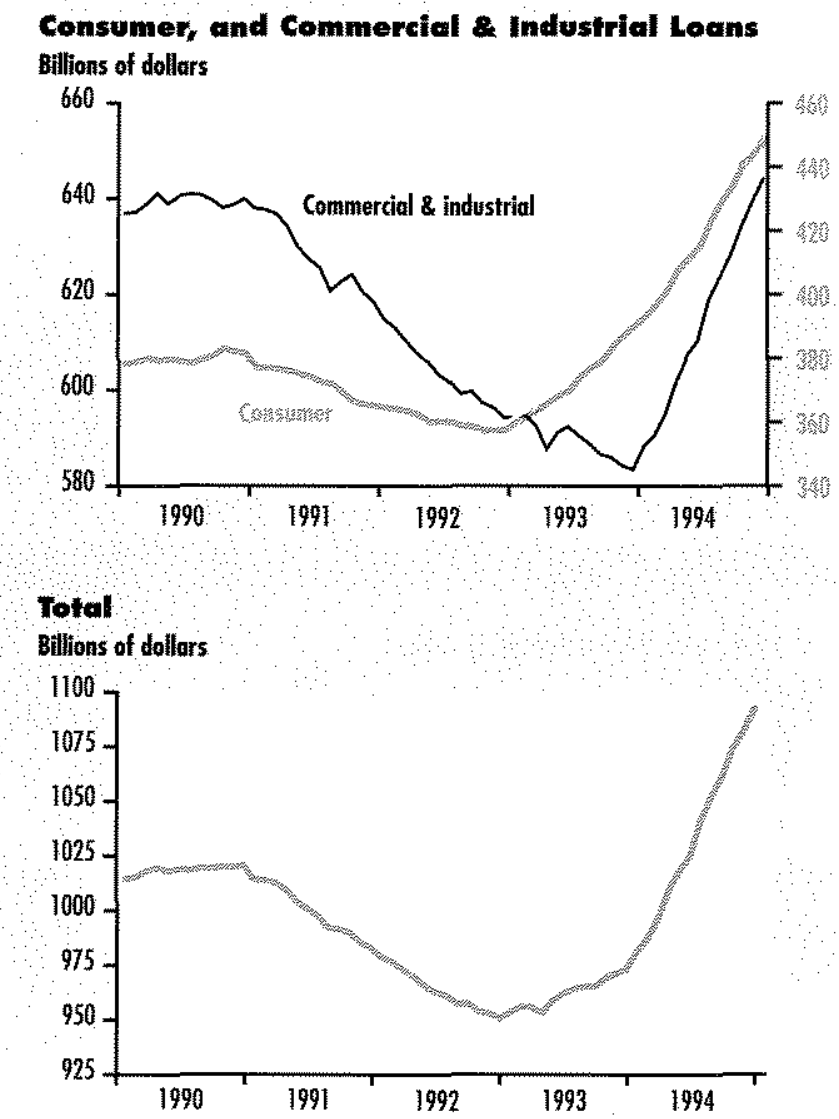

${ }^{3} 4$ Romer und Romer (1989, p. 138).

${ }^{35}$ Roner and Romer $(1989$, p. 138$)$.

${ }^{36}$ Iechnically, the stooks in Figuse 10 are the inavoutions to the funds fote equation in a theevorichle, unger sticted vecto: ouforegression (WRR), estinated using six logs of mantlly totot

${ }^{37}$ This chititista of the VAR approocts to estimeting pollcy functions has been minde befoes; see, for example, Cecthetili (1994). gence of inflationary pressures (as opposed to responding to current inflation). For example, they specifically exclude an episode in 1966, in which "the Federal Reserve's stated intent was clearly not to reduce aggregate demand, but rather to prevent outward shifts in aggregate demand that it believed would otherwise have occurred." ${ }^{34}$ The similarity to recent events is evidenced by the widespread interpretation of the Fed's 1994 policy actions as being preemptive in nature. Just as the Romers describe for 1966, "the perception of the economy's strength was based not just on current data but also on projections... ." ${ }^{\text {"35 }} \mathrm{Ex}$ post, analysts who follow a narrative approach to characterizing Fed policy might consider 1994 to constitute a policy shock, but it is not apparent that it is when one applies the ex ante criteria of the Romers.
Another approach to characterizing policy follows a statistical methodology to isolate what is known as a Federal Reserve reaction function. By examining historical data, this approach attempts to identify components of FOMC policies which are predicable reactions to emerging economic data. After controlling for these factors, the movements in the Fed's instruments which remain unexplained are interpreted as constituting policy innovations or shocks.

Figure 10 illustrates the identification of innovations using a model suggested by Bernanke and Blinder (1992). In the model used to generate the shocks illustrated in Figure 10, the federal funds rate is used as the measure of policy, and the Fed's reaction function is assumed to depend on a measure of inflation (as measured by the CPI) and a measure of real economic activity (the unemployment rate for males ages 25-54). The FOMC's reaction function is estimated to depend on inflation and unemployment over the prior six months, with the remaining movements of the fed funds rate taken to be exogenous policy innovations (that is, deliberate acts by the FOMC, rather than standard responses to emerging economic developments) ${ }^{36}$

The series of innovations illustrated in Figure 10 is much more variable than one might ordinarily associate with deliberate FOMC policy changes. ${ }^{37}$ The innovations appear more to refect random variability in the series than deliberate, discrete policy changes. It could be argued, however, that it is the cumulative effect of small innovations to the funds rate which are important in evaluating the overall thrust of monetary policy

Figure 11 shows the cumulative impact of the innovations identified in Figure 10. When the shocks are added up over time, they provide a more readily interpretable account of the thrust of monetary policy, with easily identifiable turning points. For example, this cumulative measure suggests that policy was roughly constant from 1985 through 1987 (a period when the fed funds rate itself was generally falling), then tightened rather dramatically during 1988 . The period from 1989 through 1992 is characterized by a gradual easing of policy. Note, however, that the stability of the fed funds rate during 1993 
is not associated with an unchanging policy thrust using this measure. Rather, the relatively low level of the funds rate in 1993 is associated with a series of negative shocks which, when cumulated, suggest that the policy was increasingly stimulative throughout the year.

In 1994, innovations to the funds rate were generally positive. Note, however, that the cumulative impact of innovations in 1994 did not nearly approach the level of restraint implied by this measure of policy for 1987 , when the federal funds rate itself rose by far less than it did last year. It also should be noted that Figure 11 provides little information on which to judge the absolute postition of a neutral policy stance. Although the cumulative position of the shocks end near zero, this level should be interpreted as representative of the average degree of reserve restraint over the estimation period, 1959-94. (In fact, that the cumulated residuals end the period at zero is true by construction.) This period was characterized by an average inflation rate of 4.75 percent and an unemployment rate of more than 6 percent. Hence, this level of cumulative adjustment in the funds rate is neutral only if these outcomes are deemed desirable (and if the estimated equations are, in fact, stable over time).

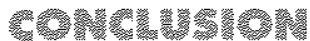

In spite of the marked contrast between the character of policy actions of the FOMC in 1993 versus 1994, in a broader context the actions of the Committee can be interpreted as part of a continuing process of evolution in the strategy and tactics of the conduct of monetary policy. The two-year period was characterized by a continuing thetoric supporting the pursuit of long-term price stability, with policy actions taken in the context of this objective.

The changing nature of the U.S. financial structure and the general economic environment, however, have made the rigorous pursuit of monetary aggregate objectives more difficult to justify, and the past two years have witnessed the Committee grappling with issues regarding the appropriate conduct of policy in the absence of reliable signals from various money stock measures.
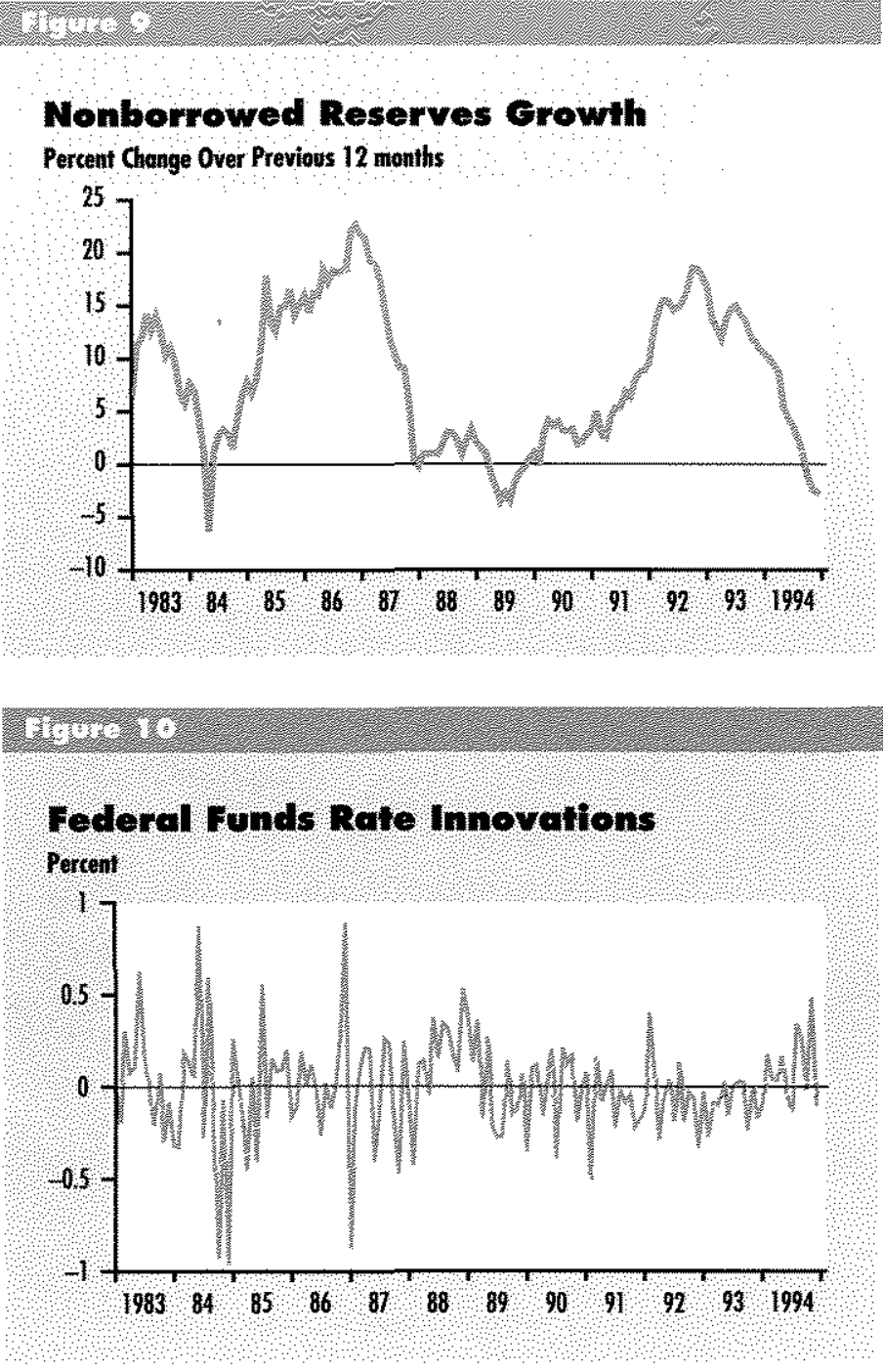

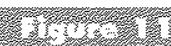

\section{Cumulative Funds Rate Innovations} Percent:

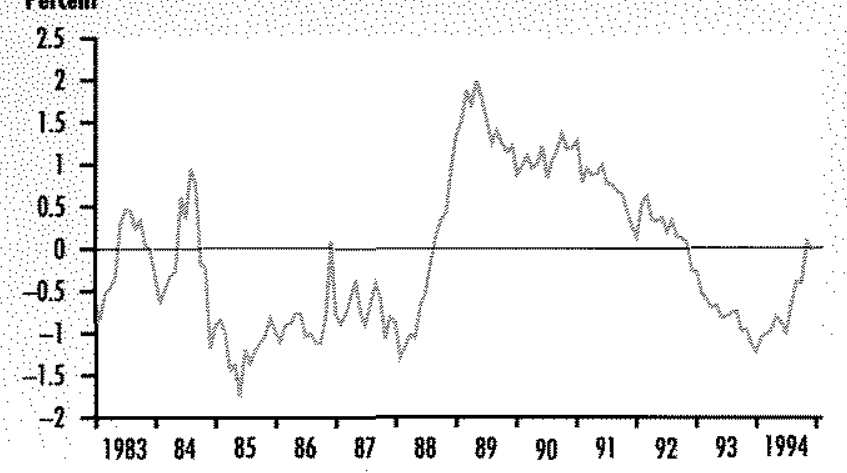


In the process of making tactical decisions, the members of the Committee reached a consensus early in 1994 that the existing policy stance was one which had remained overly accommodative, and policy actions during 1994 have been made in the context of adjusting policy to a less-accommodative posture. Unlike many other periods when the Committee reacted in response to emerging price pressures, the policy adjustments in 1994 were intended to be preemptive moves, designed to head off what the members viewed as a substantial risk of rising inflation. Hence, the lack of visible signs of an increase in inflation should not be taken as a lack of justification for the FOMCs recent stance, but as evidence of its success.

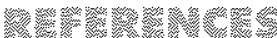

Anderson, Richatd G. "The Effect of Mortgoge Refinancing on Money Demand and the Monetary Aggregates," this Review (July/August 1993), p0. 49-63.

Angell, Woyne. "A Single Gool for the Fed," The Woll Street Journd (November 16,1994 ), p. A28.

Bernanke, Ben S., and Alon S. Binder. "The Federce Funds Rote ond the Channels of Monetary Transmission," The Americon Economic Review (September 1992), pp. 901-21.

Cecchetit, Stephen G. "Distinguishing Theories of the Monetory Tonsmission Methonism," Econamic Policy Conference, this Reviow (forthcoming).

Collins, Sean, and Cheryl L. Eowwards. "An Altenontive Monetary Aggregate: M2 Plus Household Hoddings of Band and Equity Mutsol Funds," this Review (Novernber/December 1994), pp. 7-29.

Committee of Banking, Housing, and Urben Affairs. Federol Reserve's Second Manetory Policy Report for 1993. US. Senote, July 22, 1993

Cammins, Cloudio. "Con Adjustments Help Lagging M2 to Measure Up?" American Banker, Yol 157, No. 228, (November 30, 1992), 0. 1.

Federol Reserve Bank of St. Louis. "A Price Level Objective for Manetary Policy" 1994 Annud Report (forticoning).

Federal Reserve Bufletin. Vonitus issues.

Federd Resenve Reform Act Public Low 95-188.

Feinman, Jostuo N, and Richard D. Perter. "The Continuing Weakness in M2," Finence ond Economics Discussion Series Woking Paper No. 209, (Bond of Governors of the Federal Resenve System, September 1992).

Fiedmon, Milton, and Anno Jecobsen Schwatz. A Monetory History of the United Stotes, 1867-1960. Princeton University Press, 1963.

Ful Employment and Bulanced Growth Act of 1978, Public Low 95-523 (H. S0), October 27, 1978 .
Gowin, Willom I, and Alan C. Stockman. "A Price Obtertive for Monetary Palicy" "zederal Reserve Bonk of Cleveland Economic Commentary (April 1, 1992).

Joint Economic Committee. Heang To Examine Monetary Policy and the Economic Outook. U.S. House of Reptesentotives, Decentiber 7, 1994.

Jordan, Jerry L.. "Must the Eed Fight Growtt?" Federal Reserve Bank of Cleveland fonomic Commentary (Ioly 15, 1994).

"Credibility Begins with a Clear Commitment to Price Stability" Federal Reserve Bonk of Cleveland Fconomic Commentary (0ctobes 1, 1993).

Massel, Shermon I. Monoging the Dollor. Nottan, 1973.

Meulendyke, Ann-Harie. "A Review of Federol Resene Palicy Targets and Operting Guides in Recent Decodes," in Federal Reserve Bank of New York, Internediate Torgets and Indicotors for Monetary Policy. A Crificol Survey (1990), pp. $452-73$.

Orphanides, Athanesios, Briag Reid and Eavid Smoll, "The Empirital Properties of a Monetary Agrregate That Adds Bond ond Stock Mutuat Funds to M2," this Review (November/December 1994), pp. 31-51.

Papadimiteiou, Dimitti B., and L. Randoll Wroy. "Menetary Policy Uncovered, "Public Policy Brief. The Jerome Lewy Econamics institute of Bort College, 1994.

Poole, Wilionn, "Keep the Min in Monetay Policy." Jobs and Capital (witer 1994), pp. 2-4.

Ritter, Joseph A., "The FOMC is 1992: A Monetary Conundrum, "this Review (Moy/June 1993), pe. 3749 .

Romer, Christina D., ond Dowid H. Romer. "Does Monetayy Policy Matter? A Now lest in the Spirit of Friednan and Sctwolotz," HBER Mocroeconomics Annud. Mit Press, 1989, pp. 12170.

Stone, Courtenay C, and Doniel l. Thonton. "Solving the 1980s' Veloctly Puzzle: A Progress Report," this Review (August/Septemter 1987), pp. 5-23.

Tinsley, P., J. Berry, G. Fries, B. Garrett, A. Nomman, P.A.V.B. Swamy and P. Von Zur Muehen. "The mport of Uncertintly on the Fensibitity of Humphrey-Howkins Obiectives," The Journd of Finance (May 1981). pp. $489-96$ 


\section{SUMMARY OF FOMC MEETINGS IN 1993 AND 1994}

\section{Fobruty 2-3, 1993}

At the outset of 1993, the information available to the FOMC suggested that economic activity had picked up sharply toward the end of the previous year. Committee members cited numerous conditions that led them to believe that the expansion would continue throughout 1993: "Structural impediments to the expansion seemed to be diminishing as the financial condition of households, business firms, and financial institutions continued to improve." Deficit reduction programs, expected to be announced by President Clinton, were additional signs that interest rates could fall.

Nevertheless, it was noted that "the outlook remained subject to a good deal of uncertainty." The Committee agreed, unanimously, that immediate policy should be "to maintain the existing degree of pressure on reserve positions." The directive left open the possibility of accepting either greater or lesser reserve restraint, should conditions during the intermeeting period warrant.

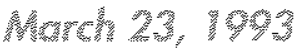

A review of recent economic activity at. the March meeting found the expansion continuing at a moderate pace in the first few months of 1993, after strong gains during the latter part of 1992. Short-term market interest rates remained relatively unchanged though long-term rates fell substantially. It was noted that in early March, "Treasury bonds and conventional fixed-rate mortgages reached their lowest levels since 1973."

The policy directive adopted by the Committee called for "maintaining the existing degree of pressure on reserve positions." Again, the Committee decided upon a symmetric directive for guiding policy during the intermeeting period.?

Governors Angell and Lindsey dissented from the Committee's decisions because they were concerned about the inflation outlook. They favored "an immediate move to tighten reserve conditions...Such an action was desir- able not only to arrest the possible emergence of greater inflation but especially to promote further disinflation."

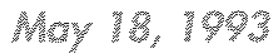

At the May 18 meeting, the FOMC was presented with staff projections which sug gested that "economic activity would grow at a moderate pace and that such growth would foster a gradual reduction in margins of unemployed labor and capital." This analysis included portions of the Clinton Administration's fiscal package pertaining to the long run. The Committee also saw "evidence of a slower economic expansion and a higher rate of inflation since late 1992..."

"In the view of a majority of the members, wage and price developments over recent months were sufficiently worrisome to warrant positioning policy for a move toward restraint should signs of intensifying inflation continue to multiply." Nevertheless, "some members preferred to retain a directive that did not incorporate a presumption about the likely direction of a change in policy..during the intermeeting period. They were concerned that adopting a biased directive might prove to be an overreaction to temporary factors and to a short-lived upturn in inflationary sentiment that was not warranted by underlying economic conditions." In the end, the Committee adopted an asymmetric directive which suggested an inclination toward greater reserve restraint rather than lesser.

There were two dissents from this decision, which reflected widely divergent perspectives. Mr. Boehne saw the adoption of a biased directive as being unwarranted, since "underlying economic conditions did not point toward an extended period of higher inflation." In contrast, Mr. Angell dissented "because he believed that the persisting indications of rising inflation...called for a prompt move to tighten monetary policy."

\section{, 覃}

In the discussion of short-term policy at the July meeting, mixed signals on the

\footnotetext{
${ }^{1}$ Al thed quototions citad in this oppentix ore dowat from ttue "Minutes of the Federd Open Wok tor Conmittee," as reported ith volious issies of the Federol Resone Bullotin.

${ }^{2} \mathrm{~A}$ "spmmeticic" diective is wodded oven bandedly with respect to possible roodificutions to policy deriteg the intermeating period. A 50 called "asymanetix" directive is one which sugnests a paefered diection for policy chonges, and is indtated by the use of the wodds "might" and "wotad," with "wolld" consitered to be the sironger of the fwo terms. For exterpla, o directive whith stotes "somewhot greater reseve restraint walled be acceptable, and sonewhot lesser resenve restrant

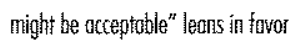
of greater reserve restacint. See Ritter (1993).
} 
performance of the economy and questions about fiscal policy "contributed to considerable uncertainty about the outlook." Some members were concerned, however, that "despite the very sluggish behavior of the broad measures of money thus far this year, monetary policy was relatively expansive as evidenced by a variety of other indicators including the growth in narrow measures of money and reserves and the very low levels of money market interest rates." Several members went on to point out that in the face of worsening inflation expectations, an unchanged policy could be more accommodative than intended.

Most members indicated that there was "little or no reason to change monetary policy in either direction." Consequently, the degree of pressure on reserve positions was left unchanged. The Committee also retained the asymmetric bias towards restraint that was adopted at the previous meeting. Mr. Angell dissented, preferring an immediate tightening of reserve restraint.

\section{A}

At the August meeting, the members of the FOMC saw little information in recent developments which would alter the "outlook for moderate and sustained growth in economic activity." Although many members noted that current policy was associated with very low short-term interest rates, there was also "no compelling evidence that current monetary policy was fostering credit flows usually associated with speculative excess or impending increases in price pressures."

With these considerations in mind, Committee members agreed "to the desirability of a steady policy course." Accordingly, the Committee voted to "maintain the existing degree of pressure on reserve positions." The directive gave no indication of a preference for altering this stance in either direction during the intermeeting period.

\section{soman}

At the September meeting, Committee members noted that general economic activity remained moderate at best, with considerable disparities existing across locales and industries. Deficit-reduction legislation that was passed in July "implied increased fiscal restraint but also appeared to have improved confidence in financial markets."

A number of factors were cited as sources of concern. New taxes associated with the deficit reduction legislation and uncertainties about health care reform were said to have generated "cautious attitudes among business executives." The outlook for net exports was also "cited as a negative factor."

The Committee decided to maintain the short-term policies of the August meeting.

\section{November 16, 1993}

Information reviewed at the November meeting continued to suggest the maintenance of a sustained, but moderate expansion. Some evidence of strengthening was cited. The Committee, however, noted that "economic activity clearly remained sluggish or even depressed in some parts of the country and overall business attitudes could still be described as cautious." Fiscal policy developments-in particular, uncertainty regarding health care reform and the ongoing retrenchment of defense spending-continued to be cited as factors which were likely "to inhibit the expansion over the year ahead." In hindsight, this view might be characterized as being overly pesw simistic: The fourth quarter of 1993 turned out to be one of the strongest quarters for economic growth in recent memory, with real GDP rising at a rate of 6.3 percent. Data revealing this strength, however, were not generally available until early 1994.

In this context, the members of the Committee unanimously agreed to support a directive which called for "maintaining the existing degree of pressure on reserve positions and that did not include a presumption about the likely direction of any adjustment to policy during the intermeeting period."

\section{Decomber 2 , 109 as}

By December, indicators were beginning to suggest that economic activity had picked up in recent months, with strength observed in consumer spending, durable equipment purchases, construction and industrial production (particularly in the automotive sector). Meanwhile, price indexes "pointed to little change in inflation trends." In their comments about recent developments, Committee 
members observed that the positive signs "had fostered appreciable improvement in business and consumer sentiment... ." Members also recognized, however, that the strengthening was not geographically uniform and that a number of factors continued to exert constraining influences. Particular concerns cited included "balance-sheet rebuilding, business restructuring and downsizing activities, and the downtrend in defense spending."

In discussing the directive for the upcoming period, most members "indicated that they could support a directive that called for maintaining the existing degree of pressure on reserve positions," with no bias toward adjusting conditions one way or the other during the intermeeting period.

Messrs. Angell and Lindsey both dissented, citing the belief that current policy was overly accommodative, and "needed to be adjusted promptly toward a more neutral stance." Mr. Angell also stressed that the Committee should focus on "forward-looking indicators such as the price of gold and the estimate of the natural rate of interest provided by the yield on fiveyear Treasury notes. He favored an immediate increase of 50 basis points in the federal funds rate...Mr. Lindsey commented further that a modest policy move now would appropriately signal the Committee's concern about the potential for inflation."

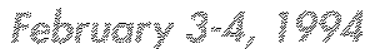

By the time of the FOMC's first meeting of 1994, incoming economic data revealed that a sharp increase in economic activity had taken place in late 1993 and that the data available for the early weeks of the year "suggested appreciable further gains."

During the Committee's discussion, "members generally expressed concern about a buildup in inflationary pressures... especially if what they currently viewed as a very accommodative monetary policy were maintained." With regard to policy for the upcoming period, members "favored an adjustment toward a less accommodative policy stance, though views differed to some extent with regard to the amount of the adjustment."

After discussing options involving the magnitude of possible policy adjustments, "all the members indicated that they could accept the proposed slight policy adjustment at this point, but many observed that additional firming probably would be desirable later." The directive adopted by the Committee at this time, however, retained an unbiased instruction with regard to possible intermeeting adjustments.

During the subsequent intermeeting period, federal funds traded at a tate of around $31 / 4$ percent-approximately $1 / 4$ percent higher than the rate that had prevailed throughout 1993.

\section{March 22, 1994}

Information reviewed at the March meeting indicated that the economy "expanded appreciably further in the early months of 1994 , despite unusually severe winter weather."

In discussing policy for the upcoming period, "all the members supported a further move toward a less accommodative policy stance." As a conceptual objective, it was agreed that policy should strive toward reaching a "more neutral position." The members generally concluded that "such a policy stance was still some distance away, and the key issue facing the Committee was not whether but by how promptly the necessary adjustment should be completed."

After a discussion of the possible magnitude of policy adjustments for the upcoming period, the Committee decided to duplicate its previous policy move, seeking to increase slightly the existing degree of pressure on reserve positions, with no explicit asymmetry in the intermeeting stance. "Messrs. Broaddus and Jordan dissented because they preferred a stronger move toward a more neutral policy stance." They viewed recent increases in long-term interest rates as indicating rising inflation expectations, and perceived that "the principal policy risk had become one of remaining accommodative for too long a period."

Subsequently, incoming data suggested considerable strength in the economy and "indications that financial markets were less likely to be destabilized by a further policy action." Against this background, on April 18, "the degree of accommodation in reserve pressures was reduced a little further." Each of the policy moves resulted in federal funds rate increases of about $1 / 4$ percent. 
Moy 17,199

At the meeting of May 17, 1994, the Committee reviewed evidence "of considerable momentum in the economic expansion." Members noted that "the expansion over the first half of the year was likely to be a little stronget than had been expected at the time of the March meeting."

In the context of current policy, Committee members "favored prompt further action to remove much of the remaining accommodation in the stance of monetary policy, at least as measured by real short-term interest rates." Consequently, the Committee adopted a directive which called on the Open Market Desk to "increase somewhat the existing degree of pressure on reserve positions." A symmetric policy toward intermeeting period adjustments was adopted. It was agreed that "the adjustment should fully reflect the $1 / 2$ percentage point increase in the discount rate that the Board of Governors was expected to approve later in the day. ${ }^{33}$

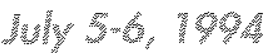

Information reviewed at the July meeting indicated that the economy grew substantially in the second quarter, but that expansion was expected to slow somewhat over the balance of the year. Given uncertainty regarding the extent of the economys slowing and the effects of previous policy moves, most FOMC members considered "that it would be prudent for the Committee to assess further developments before taking any action."

Consequently, the policy directive adopted

${ }^{3}$ Changes in the discount rote are inifioted by the individual Federal Reserve bonks, but must be approved by the Board of Governors befoie becoming effective. This division of responsibilitity underlies the rother odd ciranstances surounding increases in the federol funds rote and discousar rates in 1994. In each cose, the FOMC endersed a policy whits incorporoted expected changes in the discount rote, whict had alredy been proposed by the Fetererd Reserve banks and which were approved by the Board of Govenoes os jort of the overol palicy change. for the upcoming period called for "maintaining the existing degree of pressure on reserve positions," although it also included a bias toward the possibility of increasing the degree of reserve pressure prior to the next meeting. "Mr. Broaddus dissented because he believed that additional near-term tightening was necessary to contain inflation."

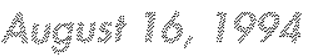

Although the pace of the economic expansion remained substantial, information reviewed by the Committee in August suggested some slowing. Staff forecasts suggested "that the economy was operating close to its long-run capacity."
The Committee generally agreed that "a prompt further tightening move was needed to provide greater assurance that inflationary pressures in the economy would remain subdued." Consequently, the FOMC approved a directive which called for "increasing somewhat the degree of pressure on reserve positions." It was agreed that if the Board of Govemors approved a $3 / 2$ percentage point increase in the discount rate (as was expected), that action should be allowed to be reflected fully in reserve market conditions. Given that members generally expected "that a further policy action was not likely to be needed for some time," the directive adopted by the Committee included a symmetric instruction regarding possible intermeeting adjustments.

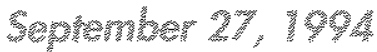

Data reviewed at the September meeting suggested that "the pace of economic expansion remained substantial, though it appeared to have moderated slightly in recent months." Moreover, staff projections "suggested that growth in economic activity would slow appreciably over the next several quarters." Previous policy moves were seen to have "elicited only a mild response thus far in interest-sensitive sectors of the economy," and output growth was "near maximum sustamable levels." It was judged that "the risks of some rise in inflation rates probably had increased."

Nevertheless, most of the Committee members felt "that the recent evidence did not warrant an immediate further tightening," given that there had been an "appreciable tightening of policy approved in August." It was expected that incoming information during the intermeeting petiod might "provide a firmer basis for judging the course of the economy and the risks of greater inflation." Consequently, the Committee approved a directive that called for "maintaining the existing degree of pressure on reserve positions," but which also included "a shift from the symmetry in the August directive to asymmetry toward restraint."

Mr. Broaddus dissented from this directive, believing "that a prompt move to somewhat greater monetary restraint was needed at this point," given "signs of increasing price pressures and rising inflationary expectations." 


\section{BEVIEW \\ MARCH/APRIL 1095}

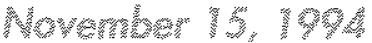

By the November meeting, incoming information suggested that "growth of the economy remained substantial," and "members commented on widespread statistical and anecdotal indications of considerably greater strength in the business expansion than they had anticipated earlier." In this context, members "saw a considerable risk of higher inflation."

In their discussion of near-term policy, "all the members agreed that the current stance of monetary policy presented unacceptable risks of embedding higher inflation in the economy." Although members "acknowledged the difficulty of judging the precise degree of monetary restraint that would be needed to attain the Committee's objectives," most members advocated "an untsually sizable furming of monetary policy." Others were reported to have "preferred a less forceful policy move," taking a more "cautious approach."

Ulimately, all members ended up supporting a directive calling for a "significant increase" in reserve pressure, which was to take account of a $3 / 4$ percentage point increase in the discount rate. Given the relative forcefulness of this move, the Committee adopted a directive that was symmetric with regard to intermeeting adjustments, although it was noted that "a symmetric directive would not prevent an intermeeting adjustment if nearterm developments differed substantially from expectations."

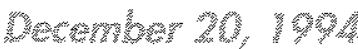

Information reviewed at the December meeting suggested "a further pickup in economic growth in recent months." The forecast presented by the staff suggested a marked slowing in economic activity over the next few quarters, but this outlook was predicated on the assumption "that monetary policy would not accommodate any continuing tendency for aggregate demand to expand at a pace that could foster sustained higher inflation." In their discussion of economic developments, Committee members "saw scant evidence at this point of any moderation in the growth of overall economic activity."

In their discussion of policy for the intermeeting period ahead, many members anticipated that "the need for further monetary restraint was highly likely." A majority, however, advocated no change in policy, at least through the beginning of 1995 , preferring a pause in order "to assess the underlying strength of the economy and the impact of previous monetary restraint." Given the probable need for further tightening at some point, a majority agreed that the directive should express an asymmetry "tilted toward restraint."

Mr. LaWare dissented from this directive, favoring an immediate policy tightening. $\mathrm{He}$ cited "high and increasing levels of utilization in labor and capital markets" as indicating a risk of rising inflation, and feared that inaction by the Committee "could heighten inflationary expectations by raising concerns about the System's commitment to the objective of sustainable, noninflationary economic growth." 